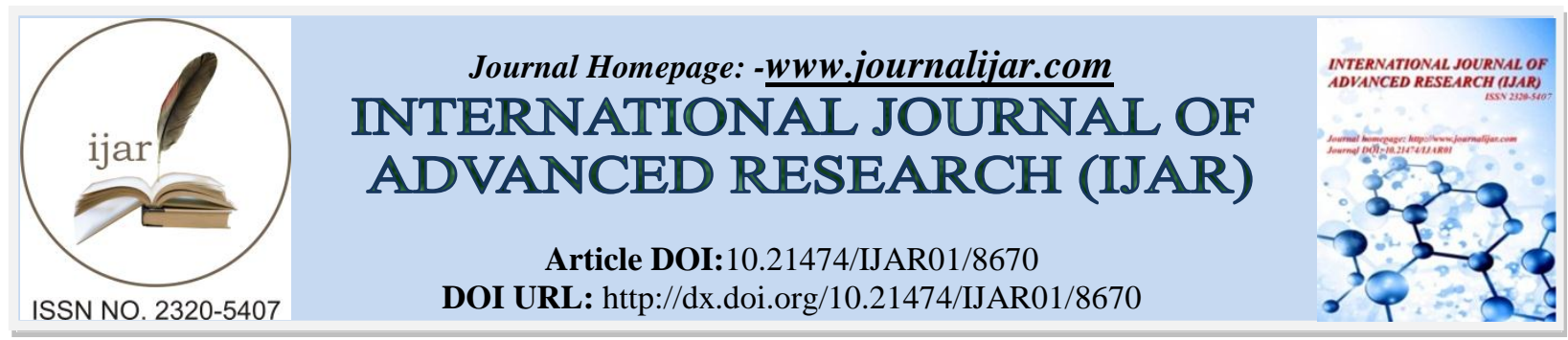

RESEARCH ARTICLE

\title{
EFFECT OF CULTIVARS ON GROWTH AND YIELD PARAMETERS IN GHERKIN (CUCUMIS SATIVUS SUB SPP. ANGURIA).
}

\section{T. Mounika ${ }^{1}$, T.S.K.K. Kiran Patro ${ }^{2}$, M. Lakshmi Narayana Reddy ${ }^{3}$, N. Emmanuel $^{4}$, D.R. Salomi Suneetha ${ }^{5}$} and B. Chennakesavulu' 6

1. Department of Vegetable Science, College of Horticulture, Dr. Y.S.R. Horticultural University, Venkataramannagudem, West Godavari Dist., A.P.

2. Technical Officer to Dean of Horticulture, College of Horticulture, Dr.Y.S.R. Horticultural University, Venkataramannagudem, West Godavari Dist., A.P.

3. Dean of Horticulture, College of Horticulture, Dr. Y.S.R. Horticultural University, Venkataramannagudem, West Godavari Dist., A.P.

4. Assistant Professor, Department of Entomology, College of Horticulture, Dr. Y.S.R. Horticultural University, Venkataramannagudem, West Godavari Dist., A.P.

5. Associate Professor, Department of Bio Chemistry, College of Horticulture, Dr. Y.S.R. Horticultural University, Venkataramannagudem, West Godavari Dist., A.P.

6. Assistant Professor, Department of Farm Engineering, College of Horticulture, Dr. Y.S.R. Horticultural University, Venkataramannagudem, West Godavari Dist., A.P.

\section{Manuscript Info}

\section{Manuscript History}

Received: 12 January 2019

Final Accepted: 14 February 2019

Published: March 2019

Key words:-

Cultivars, Chandini, growth, yield.

\begin{abstract}
An experiment was conducted during kharif, 2016 at College of Horticulture, Venkataramannagudem, West Godavari District of Andhra Pradesh to study the effect of cultivars on growth and yield parameters in gherkin. The experiment was laid out in a randomized block design (Randomized Block Design) with different cultivars (Royal, Ajax and Chandini). Chandini cultivar showed superiority over other cultivars in terms of all plant growth parameters, yield contributing parameters like fruit length, fruit diameter, mean fruit weight (20.55 g), number of fruits per vine (65.84), yield per vine (3.44 $\mathrm{kg})$, yield per plot $(61.99 \mathrm{~kg} / \mathrm{plot})$, estimated yield per hectare $(13.34$ t/ha) and 100 seed weight.
\end{abstract}

Copy Right, IJAR, 2019,. All rights reserved.

\section{Introduction:-}

Gherkin (Cucumis sativus sub spp. anguria) $(2 n=24)$, belongs to the family Cucurbitaceae. It is popularly known as "Pickling cucumber" or small cucumber among farmers. It is monoecious, annual, trailing or climbing vine, which branches freely with slender, rough hairy, angled stems and tendrils. The leaves are 3 to 5 angled, shallow lobed with acute sinuses and 7 to $15 \mathrm{~cm}$ in length and oval to oblong in shape and born on long slender stalks. They are light green and turn yellowish when fully matured with or without spiky surface covered with long sharp glistering hairs. Flower is yellow in colour. The flesh is greenish in colour with many seeds. Seeds are small, white, smooth, 3 to 5 $\mathrm{mm}$ long. The immature fruits are used for the preparation of pickles, eaten as a cooked vegetable and are used in curries (Purseglove, 1969). The fruits and seed possess cooling properties. The fruit is also used as an astringent and antipyretic. The seed oil is used as antipyretic. Fruits are good for people suffering with constipation, jaundice and 
indigestion. Gherkins pickled in brine are a favourite lunch substitute in west. Gherkin is commonly grown in USA, Australia and Sri Lanka and is being consumed in European countries. The market demand is on the increase in America and Australia. Traditionally Spain, Morocco, Turkey and Bulgaria are the leading producers at the global level. Due to the availability of the produce only for one season, high labour cost and other related problems, the European countries encourage production in developing countries like India where good agroclimatic conditions exist can produce gherkin round the year (Anonymous, 1995). Gherkin was introduced in India during late eighties on a trial basis for the first time in Karnataka. However, looking at the good demand for this export oriented crop, its cultivation is extended to parts of Andhra Pradesh and Tamil Nadu (Anonymous, 1996). Now a days it is also grown in West Bengal and some parts of North India. It is a warm season crop and a temperature range of $18^{\circ}-32^{\circ} \mathrm{C}$ is ideal for its growth and yield. The crop grows on a variety of soils rich in organic matter having a good drainage (Curwen, 1979). The production of gherkin in India is concentrated in Southern states Karnataka, Tamil Nadu and Andhra Pradesh.

Gherkin is a quick income generating crop, the industry soon became popular over the last two decades and are also referred to as "cornichos" which is the French word for gherkin. It has been used in folk medicine to treat ailments. They are low in calories and fat. It has small amounts of potassium, iron, vitamin K. They were believed to have been the first ever pickle. It is propagated by using seeds.

The main objective of the grower is to produce maximum yield at the time when prices are high. This requires skillful decisions regarding selection of cultivars.

Hence, standardization of good cultivar for obtaining better growth and yield of gherkin is very important as this crop is a new introduction to this area. Therefore, the present investigation was carried out with this aim.

\section{Materials and Methods:-}

The present experiment was conducted during kharif, 2016 at College farm, College of Horticulture, Venkataramannagudem, West Godavari District. The experiment was laid out in a randomized block design (RBD) with different cultivars (Royal, Ajax and Chandini). The experimental area of $448 \mathrm{~m}^{2}$ was divided into beds of $5 \mathrm{~m} \mathrm{x}$ $1.5 \mathrm{~m}$ size. Irrigation channels of $1 \mathrm{~m}$ size were provided between two beds. Treatments were randomly distributed according to randomized block arrangement. Seeds were sown at a required spacing of $45 \mathrm{x} 75 \mathrm{~cm}$ distance. Sowing of the seeds was taken at a depth of less than $1 \mathrm{~cm}$ on raised beds of height $15 \mathrm{~cm} .3-4$ seeds were sown in each pit during first week of July. Each bed consisted of 12 plants, of which five competitive plants were selected at random for recording the observations. The crop was raised as per the recommended package of practices. Data was statistically analyzed by the methods outlined by Panse and Sukhatme (1985).

\section{Results and Discussion:-}

The analysis of variance (ANOVA) revealed significant differences among all treatment combinations in respect to growth parameters and yield parameters.

The effect of cultivars was found highly significant in most of the parameters. Chandini cultivar was found to be superior over Ajax cultivar followed by Royal cultivar. In terms of growth parameters, Chandini cultivar has shown less number of days for emergence (5.28), highest percentage of germination (77.16), longest main vine length $(124.28 \mathrm{~cm})$, highest number of nodes per vine $(32.24)$, shortest internodes $(4.21 \mathrm{~cm})$, more number of primary branches per vine (7.46), less number of days taken for first female flower opening (28.18), more number of days taken for first male flower opening (21.92) and node at which first flower appeared (5.51). These results are in close conformity with the results obtained by Al-Rawahi et al., (2011) in cucumber.

The increase in vegetative growth as evidenced by the increased number of branches per vine and maximum vine length might have resulted in faster and more synthesis and translocation of photosynthates from source (leaves) to sink (fruit) resulting in maximum number of fruits.

In terms of yield parameters also Chandini cultivar showed significantly superiority over other cultivars in terms of days to first harvest (37.34), number of fruits per vine $(65.84)$, fruit length $(5.35 \mathrm{~cm})$, fruit diameter $(2.94 \mathrm{~cm})$, mean fruit weight $(20.55 \mathrm{~g})$, yield per vine $(3.44 \mathrm{~kg})$, yield per plot $(61.99 \mathrm{~kg} / \mathrm{plot})$, yield per hectare $(13.34 \mathrm{t} / \mathrm{ha})$, hundred seed weight $(3.90 \mathrm{~g})$, days from fruit set to maturity (11.46) and fruit retention percentage (78.90) but number of seeds 
per fruit was found to be non-significant. Among the cultivars Chandini cultivar was found to show superior values throughout the study. The superiority might be due to ready availability of nutrients, their improved absorption and translocation by plants more quickly, which resulted in higher photosynthetic activity. Similar observations were recorded by Ashwini (2014) in snake gourd, Keerthika et al., (2016) in cucumber and Sithole et al., (2015) in bottle gourd.

\section{Conclusion:-}

Chandini cultivar performed better than other cultivars in all characters. From the results of the present investigation, it can be concluded that the Chandini cultivar proved to be the best for cultivation of gherkin in light soils of coastal Andhra Pradesh for getting higher economic yield.

Table 1:-Effect of cultivars on growth parameters in gherkin

\begin{tabular}{|l|l|l|l|l|l|l|l|l|l|}
\hline Cultivar & $\begin{array}{l}\text { Days to } \\
\text { first } \\
\text { seedling } \\
\text { emergen } \\
\text { ce }\end{array}$ & $\begin{array}{l}\text { Percentag } \\
\text { e of } \\
\text { germinati } \\
\text { on (\%) }\end{array}$ & $\begin{array}{l}\text { Main } \\
\text { vine } \\
\text { length } \\
(\mathbf{c m})\end{array}$ & $\begin{array}{l}\text { Node } \\
\text { s per } \\
\text { vine }\end{array}$ & $\begin{array}{l}\text { Intermoda } \\
\text { length } \\
(\mathbf{c m})\end{array}$ & $\begin{array}{l}\text { Primary } \\
\text { branche } \\
\text { s per } \\
\text { vine }\end{array}$ & $\begin{array}{l}\text { Days } \\
\text { taken } \\
\text { for } \\
\text { first } \\
\text { female } \\
\text { flower } \\
\text { openin } \\
\text { g }\end{array}$ & $\begin{array}{l}\text { Days } \\
\text { taken } \\
\text { for } \\
\text { first } \\
\text { male } \\
\text { flower } \\
\text { openin } \\
\text { g }\end{array}$ & $\begin{array}{l}\text { Node at } \\
\text { which } \\
\text { first } \\
\text { flower } \\
\text { appeare } \\
\text { d }\end{array}$ \\
\hline Royal & 12.68 & 68.13 & 119.06 & 29.96 & 4.80 & 6.78 & 30.40 & 20.98 & 5.97 \\
\hline Ajax & 7.54 & 76.20 & 119.16 & 31.22 & 4.56 & 7.40 & 28.20 & 21.29 & 5.53 \\
\hline Chandini & 5.28 & 77.16 & 124.28 & 32.24 & 4.21 & 7.46 & 28.18 & 21.92 & 5.51 \\
\hline SE(m) & 0.22 & 1.32 & 1.61 & 0.81 & 0.11 & 0.13 & 0.51 & 0.14 & 0.10 \\
\hline CD at 5\% & 0.65 & 3.84 & 4.69 & 2.38 & 0.34 & 0.39 & 1.50 & 0.42 & 0.29 \\
\hline
\end{tabular}

Table 2:-Effect of cultivars on yield parameters in gherkin

\begin{tabular}{|l|l|l|l|l|l|l|l|l|l|l|l|}
\hline $\begin{array}{l}\text { Cultiva } \\
\text { r }\end{array}$ & $\begin{array}{l}\text { Days } \\
\text { to } \\
\text { first } \\
\text { harve } \\
\text { st }\end{array}$ & $\begin{array}{l}\text { Numb } \\
\text { er of } \\
\text { fruits } \\
\text { per } \\
\text { vine }\end{array}$ & $\begin{array}{l}\text { Fruit } \\
\text { lengt } \\
\mathbf{h} \\
\text { (cm) }\end{array}$ & $\begin{array}{l}\text { Fruit } \\
\text { diamet } \\
\text { er }(\mathbf{c m})\end{array}$ & $\begin{array}{l}\text { Mea } \\
\mathbf{n} \\
\text { fruit } \\
\text { weig } \\
\text { ht }(\mathbf{g})\end{array}$ & $\begin{array}{l}\text { Yiel } \\
\text { d } \\
\text { per } \\
\text { vine } \\
\text { (kg) }\end{array}$ & $\begin{array}{l}\text { Yield } \\
\text { per } \\
\text { plot } \\
\text { (kg/plo } \\
\text { t) }\end{array}$ & $\begin{array}{l}\text { Yield } \\
\text { per } \\
\text { hecta } \\
\text { re } \\
\text { (t/ha) }\end{array}$ & $\begin{array}{l}\text { Hundr } \\
\text { ed seed } \\
\text { weight } \\
\text { (g) }\end{array}$ & $\begin{array}{l}\text { Days } \\
\text { from } \\
\text { fruit } \\
\text { set to } \\
\text { maturi } \\
\text { ty }\end{array}$ & $\begin{array}{l}\text { Fruit } \\
\text { retention } \\
\text { percenta } \\
\text { ge }(\%)\end{array}$ \\
\hline Royal & 42.91 & 60.92 & 4.84 & 2.58 & 19.13 & 2.77 & 53.95 & 10.51 & 3.58 & 12.46 & 66.80 \\
\hline Ajax & 41.49 & 61.23 & 5.01 & 2.69 & 19.65 & 3.03 & 50.66 & 12.27 & 3.59 & 11.48 & 77.13 \\
\hline $\begin{array}{l}\text { Chandi } \\
\text { ni }\end{array}$ & 37.34 & 65.84 & 5.35 & 2.94 & 20.55 & 3.44 & 61.99 & 13.34 & 3.90 & 11.46 & 78.90 \\
\hline SE(m) & 0.95 & 1.12 & 0.11 & 0.07 & 0.36 & 0.09 & 1.70 & 0.64 & 0.08 & 0.30 & 1.73 \\
\hline $\begin{array}{l}\text { CD at } \\
\mathbf{5 \%}\end{array}$ & 2.77 & 3.28 & 0.32 & 0.21 & 1.06 & 0.27 & 4.97 & 1.86 & 0.24 & 0.89 & 5.06 \\
\hline
\end{tabular}

\section{Acknowledgements:-}

I extend my deep sense of reverence and gratitude to Associate Dean, College of Horticulture, Venkataramannagudem, Dr. YSRHU for providing financial assistance in the form of stipend to complete this endeavour. 


\section{References:-}

1. Alenazi, M., Abdel-Razzak, H., Ibrahim, A., Wahb-Allah, M. and Alsadon, A. 2015. Response of muskmelon cultivars to plastic mulch and irrigation regimes under greenhouse conditions. Journal of Animal and Plant Sciences, 25(5): 1398-1410.

2. Al-Rawahi, M., Al-Said, F.A., Khan, I.A. and Al-Khanjary, S. 2011. Diversity of cucumber accessions in Oman. International Journal of Environment and Agriculture Resources, 13(4): 505-510.

3. Anonymous. 1995. Gherkins (Cucumis sativus L.). Farm Digest, 1-3: 6-8.

4. Anonymous. 1996. Gherkins production and export in India. Business Line, $17^{\text {th }}$ April.

5. Ashwini, K. 2014. Studies on the performance of F1 hybrids and their parents in snake gourd (Trichosanthes anguina L.) for yield and yield attributing characters. http:// krishikosh.egranth.ac.in/handle/1/69482.

6. Keerthika, T., Devaki, C.S., Suma, F. and Urooj, A. 2016. Studies on the nutritional and quality characteristics of Cucumis sativus varieties. Agriculture Science and Resources Journal, 6(4): 79-85.

7. Panse, V.G. and Sukhatme, P.V. 1985. Statistical methods for agricultural workers. Indian Council of Agricultural Research, New Delhi.

8. Purseglove, J.W. 1969. Tropical Crops Dicotyledons-1. Longmans Green and Co. Ltd pp, 109-110.

9. Sithole, N.J., Modi, A.T. and Mabhaudhi, T. 2015. Seed quality of selected bottle gourd landraces compared with popular cucurbits. South African Journal of Plant \& Soil. 33(2): 133-139. 